\title{
TEMPORAL EVOLUTION OF THE LOWER HYBRID CAVITIES IN THE IONOSPHERE PLASMA DUE TO TURBULENT DIFFUSION
}

\author{
N.A. Azarenkov ${ }^{1}$, D.V. Chibisov $^{1}$, N.I. Kovalenko ${ }^{2}$, D.I. Maslennikov ${ }^{2}$ \\ ${ }^{1}$ V.N. Karazin Kharkiv National University, Kharkiv, Ukraine; \\ ${ }^{2}$ Kharkiv National Agrarian University, «Dokuchaievske-2», Kharkiv region, Ukraine \\ E-mail: dmitriychibisov@karazin.ua
}

The problem of evolution and disappearance of the lower hybrid cavities that are observed in the plasma of the Earth's ionosphere is solved. It is assumed that the destruction of the cavity is caused by turbulent diffusion of plasma, which arises due to the drift instability of radially inhomogeneous plasma. The initial plasma density distribution on the radius in the cavity is considered to be the inverse Gaussian distribution. A solution of the diffusion equation is obtained, which at any time determines the radial dependence of the plasma density in the cavity. In the asymptotic limit $t \rightarrow \infty$ the plasma density in the cavity becomes equal to the density of the surrounding plasma.

PACS: 52.35.Qz, 52.35.Ra, 94.20.wf

\section{INTRODUCTION}

Lower hybrid cavities (LHC) are axisymmetric solitary structures in the Earth's ionosphere, elongated along the geomagnetic field, in which the plasma density is depleted compared to the surrounding plasma [1]. A characteristic feature of cavities is also an enhanced level of lower hybrid oscillations compared with ambient hiss. These two features are quite accurately reflected in the name of these structures. LHCs are detected by satellites as well as by sounding rockets and are observed only when they pass directly through cavities. Since the time of cross of the cavity by the spacecraft is short, the possibilities for detailed study of the LHC are limited. In particular, the moments of appearance of such structures, as well as their disappearance, have not been detected. Despite the fact that quite a lot of research data has been obtained, there is still no acceptable theory of the origin of LHC. There is also no explanation for their stability, but at the same time, the origin of the oscillations is explained by the presence of an azimuthal current caused by a non-uniform plasma density [1]. For a long time, no attention was paid to the problem of the destruction of cavities. In our paper [2] was suggested that the destruction of LHC is caused by the anomalous diffusion of ions and electrons, which occurs due to the development of drift turbulence of radially inhomogeneous plasma. It was shown that radial in homogeneity of plasma density leads to the development of the drift instability and drift turbulence of plasma in the cavity. For the conditions of LHC the estimates of values of the frequency, as well as the growth rate of drift oscillations were made. In addition, the average time of plasma diffusion in the cavity was preliminarily estimated. A comparison of these average times showed that the plasma diffusion rate is less than the oscillation growth rate. Apparently, this can explain the absence of a low-frequency spectrum of oscillations in the LHC, measured by a spacecraft.

In this paper, which is a development of work [2], the problem of the plasma density temporal evolution in a cavity due to the anomalous transport across the magnetic field caused by drift turbulence in radially inhomogeneous plasma is considered in detail. In particular, more accurate estimates of the diffusion rate, which correct the time of destruction of the cavity, are made.

\section{EVOLUTION OF PLASMA DENSITY DEPENDENCE ON RADIUS}

In homogeneous magnetized plasma, the density of which is $n_{0}$, we consider a cavity with axial symmetry, whose axis coincides with the direction of the magnetic field. It is assumed that the initial dependence of the plasma density on the radius in the cavity is [2]

$$
n(r)=n_{0}\left(1-a \exp \left(-\frac{r^{2}}{2 r_{0}^{2}}\right)\right),
$$

which is the inverse Gaussian distribution. In (1) $r_{0}$ is the length of the in homogeneity of plasma density, $a$ is the positive constant, which is the depth of the cavity. The dependence (1) is confirmed by observations [1]. As a result of the development of drift turbulence due to the radial in homogeneity of plasma, anomalous transport of ions and electrons across the magnetic field occurs, which is governed by the diffusion equation

$$
\frac{\partial n_{e, i}}{\partial t}=\frac{1}{r} \frac{\partial}{\partial r}\left(r D_{e, i \perp} \frac{\partial n_{e, i}}{\partial r}\right),
$$

where subscripts $e$ and $i$ denotes the electrons and ions, $D_{e, i \perp}$ is the diffusion coefficient across the magnetic field, which is the same for electrons and ions, since diffusion is ambipolar. The value of $D_{e, i \perp}$ is [3 - 5]

$$
D_{e, i \perp}=\frac{c^{2}}{B_{0}^{2}} \sum_{m} \int d k \frac{m^{2}}{r^{2}} J_{m}^{2}\left(k_{\perp} R_{e}\right) I_{m}(k) \frac{\gamma_{m}(k)}{\omega_{m}^{2}(k)},
$$

where $\gamma_{m}(k)$ and $\omega_{m}(k)$ are the growth rate and the frequency of drift oscillations in LHC [2]. For drift turbulence in the saturation state, the diffusion coefficient is [3 - 5]

$$
D_{e, i \perp}=\frac{c T_{e}}{e B_{0}} \frac{\rho_{s}}{r_{0}} .
$$

To solve the equation (2), we introduce the notation $4 D_{e, i \perp}=D$ and rewrite (2) as

$$
\frac{\partial n}{\partial t}=\frac{\partial}{\partial r^{2}}\left(r^{2} D \frac{\partial n}{\partial r^{2}}\right)
$$

Take the Laplace transform of eq. (4) by multiplying both sides of it by $\exp \left(-p r^{2}\right)$ and integrate over $r^{2}$ 


$$
\frac{\partial}{\partial t}\left(\int_{0}^{\infty} n(r, t) e^{-p r^{2}} d r^{2}\right)=\int_{0}^{\infty} e^{-p r^{2}} \frac{\partial}{\partial r^{2}}\left(r^{2} D \frac{\partial(r, t)}{\partial r^{2}}\right) d r^{2} .
$$

Denote

$$
N=N(p, t)=\int_{0}^{\infty} n(r, t) e^{-p r^{2}} d r^{2},
$$

which is the Laplace transform for plasma density by the squared radial coordinate. Then we get the equation

$$
\frac{\partial N}{\partial t}=\int_{0}^{\infty} e^{-p r^{2}} \frac{\partial}{\partial r^{2}}\left(r^{2} D \frac{\partial n}{\partial r^{2}}\right) d r^{2} .
$$

Now we integrate the right side of (6) by parts twice and obtain:

$$
\frac{\partial N}{\partial t}=-p \int_{0}^{\infty} n\left(-p e^{-p r^{2}} r^{2} D+e^{-p r^{2}} \frac{\partial}{\partial r^{2}}\left(r^{2} D\right)\right) d r^{2} .
$$

Suppose that the diffusion coefficient does not depend on the radius, and then this equationis simplified

$$
\frac{\partial N}{\partial t}=p^{2} D \int_{0}^{\infty} n e^{-p r^{2}} r^{2} d r^{2}-p D N
$$

For the first term in (7), we use differentiation by parameter

$$
\begin{gathered}
p^{2} D \int_{0}^{\infty} n e^{-p r^{2}} r^{2} d r^{2}= \\
=-p^{2} D \frac{\partial}{\partial p}\left(\int_{0}^{\infty} n e^{-p r^{2}} d r^{2}\right)=-p^{2} D \frac{\partial N}{\partial p} .
\end{gathered}
$$

As a result, the eq. (7) for $N(p, t)$ becomes

$$
\frac{\partial N}{\partial t}=-p^{2} D \frac{\partial N}{\partial p}-p D N
$$

or

$$
\frac{\partial N}{\partial t}+p^{2} D \frac{\partial N}{\partial p}=-p D N
$$

To solve the partial differential equation (9), we use the method of characteristics. First integral of the eq. (9) we find from the characteristic equation

$$
\frac{d t}{1}=\frac{d p}{D p^{2}}
$$

The solution of eq. (10), i.e. the first integral of eq. (9) is

$$
u=t+\frac{1}{D p} .
$$

Now we get the second integral of eq. (9). For this we rewrite eq. (9) as

$$
\frac{\partial N}{\partial t}+p^{2} D \frac{\partial N}{\partial p}=-p D N \frac{\partial N}{\partial N}
$$

Then we obtain second characteristic equation for

$$
\frac{d p}{p}=-\frac{d N}{N} .
$$

So the second integral is

$$
v=N p .
$$
(9):

First and second integrals give a general solution of

$$
v=g(u),
$$

where $g$ is an arbitrary function. Substituting (11) and (13) into (14) we obtain

$$
N p=g\left(t+\frac{1}{D p}\right),
$$

or

$$
N(p, t)=\frac{1}{p} g\left(t+\frac{1}{D p}\right) .
$$

Now we take into account the initial dependence (i. e. at $t=0$ ) of plasma density on the radius (1). Solving the diffusion equation (9), we consider only second term in (1), since the first does not depend on either time or coordinate. Thus we study the evolution of the distribution

$$
n(r)=n_{0} a e^{-\frac{r^{2}}{2 r_{0}^{2}}} .
$$

Find the Laplace transform of (16)

$$
N_{0}(p)=n_{0} a \int_{0}^{\infty} e^{-\frac{r^{2}}{2 r_{0}^{2}}} e^{-p r^{2}} d r^{2}=\frac{n_{0} a}{p+\frac{1}{2 r_{0}^{2}}},
$$

and substitute it into (15) where we assume $t=0$. Thereby we find the function $N_{0}(p)$ for the initial moment of time

$$
N_{0}(p)=\frac{n_{0} a}{p+\frac{1}{2 r_{0}^{2}}}=\frac{1}{p} g\left(\frac{1}{D p}\right) .
$$

Thus we found the explicit form of the function $g$ (14):

$$
g(x)=\frac{n_{0} a}{1+\frac{D}{2 r_{0}^{2}} x} .
$$

Now we substitute into (19) instead of $x$ the value

$$
x=t+\frac{1}{D p},
$$

that yields time dependence of $N(p, t)$ :

$$
N(p, t)=\frac{1}{p} \frac{n_{0} a}{1+\frac{D}{2 r_{0}^{2}}\left(t+\frac{1}{D p}\right)},
$$

or, otherwise

$$
N(p, t)=\frac{n_{0} a}{\left(1+\frac{D}{2 r_{0}^{2}} t\right)} \cdot \frac{1}{p+\frac{1}{2 r_{0}^{2}\left(1+\frac{D}{2 r_{0}^{2}} t\right)}} .
$$

To obtain the dependency $n(r, t)$, we take the inverse Laplace transform for $N(p, t)(20)$ :

$$
\begin{gathered}
n(r, t)=\frac{1}{2 \pi i} \int_{s-i \cdot \infty}^{s+i \cdot \infty} N(p, t) e^{p r^{2}} d p= \\
=\frac{n_{0} a}{\left(1+\frac{D}{2 r_{0}^{2}} t\right)} e^{-\frac{r^{2}}{2 r_{0}^{2}}\left(1+\frac{D}{2 r_{0}^{2}} t\right)^{-1}} .
\end{gathered}
$$

Now in (21) we back to the original diffusion coefficient $D=4 D_{e, i \perp}$ and obtain 


$$
n(r, t)=\frac{n_{0} a}{\left(1+\frac{2 D_{e, i \perp}}{r_{0}^{2}} t\right)} e^{-\frac{r^{2}}{2 r_{0}^{2}}\left(1+\frac{2 D_{e, i \perp}}{r_{0}^{2}} t\right)^{-1}} .
$$

Finally, we get the dependence of plasma density in the cavity on the radius and on time as

$$
n(r, t)=n_{0}\left(1-\frac{a}{\left(1+\frac{2 D_{e, i \perp}}{r_{0}^{2}} t\right)} e^{-\frac{r^{2}}{2 r_{0}^{2}}\left(1+\frac{2 D_{e, i \perp}}{r_{0}^{2}} t\right)^{-1}}\right) .
$$

In (23), the depth of the cavity is determined by

$$
a(t)=\frac{a}{\left(1+\frac{2 D_{e, i \perp}}{r_{0}^{2}} t\right)} .
$$

It follows from (24) that the depth of the cavity is inversely proportional to time and in the asymptotic limit $t \rightarrow \infty$ the plasma density in the cavity tends to the density of the surrounding plasma. In addition, the cavity expands with time; the root-mean-square radial size of the cavity varies with time as

$$
\sigma(t)=r_{0} \sqrt{1+\frac{2 D_{e, i \perp}}{r_{0}^{2}} t} .
$$

Let us estimate now the time of evolution of the plasma density distribution in the cavity on the radius. Characteristic values of plasma parameters in the cavity are [1]: $r_{0} / \rho_{s} \gtrsim 3, r_{0} \gtrsim 5 \mathrm{C} m, B_{0} \sim 0.2 \mathrm{Gs}, T_{e} \sim 0.3 \mathrm{eV}$. For these parameter values the diffusion coefficient (3) is $D_{e, i \perp}=5 \cdot 10^{7} \mathrm{~cm}^{2} \cdot \mathrm{s}^{-1}$. Denote $k$ the ratio of the depth of the cavity at the initial and arbitrary points in time,

$$
k=\frac{a}{a(t)}=\left(1+\frac{2 D_{e, i \perp}}{r_{0}^{2}} t\right),
$$

and obtain the time $t_{k}$, which corresponds to the change in the depth of the cavity by $k$

$$
t_{k}=\frac{(k-1)}{2 D_{e, i \perp}} r_{0}^{2} .
$$

Substituting known values into (27), we get

$$
t_{k}=0.25(k-1) \text {. }
$$

For example, a decrease in cavity depth by 2 times will occur in $0.25 \mathrm{~s}$, and a decrease in cavity depth by 5 times occurs in $1 \mathrm{~s}$. The time evolution of the dependence of the plasma density in the cavity on the radius is shown in the Figure, where the plasma densities versus radius are shown for different moments of time: $t_{0}=0 s, t_{1}=0.25 s, t_{2}=0.5 s t_{3}=0.75 s, t_{4}=1 s$ at initial cavity depth $a=0.6$.

Note that the time of development of the drift instability in the cavity is $0.5 \ldots 1.5 \mathrm{~s}$ [2] and this time value should be added to the diffusion time. Therefore the complete disappearance of the cavity will occur in the order of a few seconds.

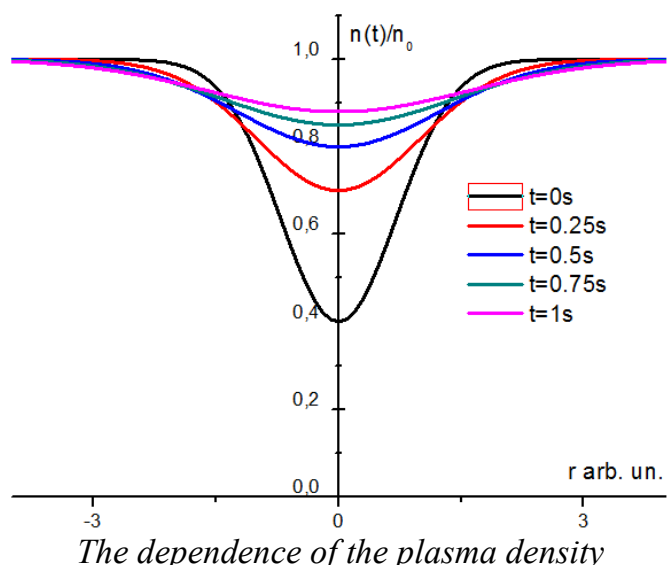

in the cavity on the radius for different moments of time

\section{CONCLUSIONS}

Radial in homogeneity of the plasma density in the LHC causes the drift turbulence and anomalous diffusion of ions and electrons to the center of the LHC across the magnetic field. Plasma diffusion leads to the temporal evolution of the dependence of the plasma density on the radius in accordance with (23).

The depth of the cavity is inversely proportional to time (24) and in the asymptotic limit $t \rightarrow \infty$ the plasma density in the cavity tends to the density of the surrounding plasma. The time to decrease the depth of the cavity in $k$ times is proportional to $(k-1)$ (27). Simultaneously with a decrease in the depth of the cavity, its expansion occurs. Root-mean-square radial size of the cavity is proportional to the square root of time (25).

Estimation of plasma diffusion time in the cavity, taking into account the time of development of the drift instability, shows that the destruction of the cavity occurs within a few seconds. Thus, spacecraft are not able to detect the process of destruction of the cavity, since the observation time by them is much less than the time of the existence of the cavity.

\section{REFERENCES}

1. P.W. Schuck, J.W. Bonnell, P.M. Kintner. A review of lower hybrid solitary structures // IEEE Trans. Plasma Sci. 2003, v. 31, № 6, p. 1125-1177.

2. N.A. Azarenkov, D.V. Chibisov. Anomalous diffusion of plasma in the lower hybrid cavities observed in the terrestrial ionosphere // Problems of Atomic Science and Technology. Series "Plasma Physics". 2018, № 6, p. 117-120.

3. D.V. Chibisov, V.S. Mikhailenko, K.N. Stepanov. Drift wave turbulence of a radially inhomogeneous plasma // Phys. Lett. A. 1991, v. 157, p. 141-145.

4. V.S. Mikhailenko, K.N. Stepanov, D.V. Chibisov. Drift and drift-cyclotron turbulence of a radially varying axisymmetric plasma // Soviet Journal of Plasma Physics. 1991, v. 17, № 10, p. 710-716.

5. V.S. Mikhailenko, K.N. Stepanov, D.V. Chibisov. Drift turbulence of an azimutally symmetric radially nonuniform plasma // Plasma Phys. Rep. 1995, v. 21, № 12, p. 141-150. 


\title{
ВРЕМЕННАЯ ЭВОЛЮЦИЯ НИЖНЕГИБРИДНЫХ ПОЛОСТЕЙ В ИОНОСФЕРНОЙ ПЛАЗМЕ ВСЛЕДСТВИЕ ТУРБУЛЕНТНОЙ ДИФФУЗИИ
}

\section{Н.А. Азаренков, Д.В.Чибисов, Н.И. Коваленко, Д.И. Масленников}

Решается проблема эволюции и исчезновения нижнегибридных полостей, наблюдаемых в плазме ионосферы Земли. Предполагается, что разрушение полости вызвано турбулентной диффузией плазмы, которая возникает из-за дрейфовой неустойчивости радиально-неоднородной плазмы. В качестве начального радиального распределения плотности плазмы в полости рассматривается обратное распределение Гаусса. Получено решение уравнения диффузии, которое в любой момент времени определяет зависимость от радиуса плотности плазмы в полости. Показано, что в асимптотическом пределе $t \rightarrow \infty$ плотность плазмы в полости становится равной плотности окружающей плазмы.

\section{ЕВОЛЮЦІЯ В ЧАСІ НИЖНЬОГІБРИДНИХ ПОРОЖНИН В ІОНОСФЕРНІЙ ПЛАЗМІ ВНАСЛІДОК ТУРБУЛЕНТНОЇ ДИФУЗЇ̈}

\author{
М.О. Азарєнков, Д.В. Чібісов, М.І. Коваленко, Д.І. Масленніков
}

Вирішується проблема еволюції і зникнення нижньогібридних порожнин, які спостерігаються в плазмі іоносфери Землі. Передбачається, що руйнування порожнини викликане турбулентною дифузією плазми, яка виникає через дрейфову нестійкість радіально-неоднорідної плазми. В якості початкового радіального розподілу щільності плазми в порожнині розглядається зворотній розподіл Гаусса. Отримано рішення рівняння дифузії, яке в будь-який момент часу визначає залежність від радіуса щільності плазми в порожнині. Показано, що в асимптотичній границі $t \rightarrow \infty$ щільність плазми в порожнині стає рівною щільності навколишньої плазми. 